\title{
Peluang dan Hambatan Publikasi Artikel pada Jurnal Internasional Bereputasi: Studi Eksploratori pada Mahasiswa Doktoral di Sebuah Perguruan Tinggi Swasta di Jakarta
}

Agus Purwanto*, Rudy Pramono, Innocentius Bernarto, Masduki Asbari, Priyono Budi Santoso, Freddy Ong, Williana Kusumaningsih, Anggaripeni Mustikasiwi, Mirza Prameswari, Laksmi Mayesti Wijayanti, Choi Chi Hyun

Universitas Pelita Harapan, Indonesia

Corresponding email : agozpor@gmail.com

Receive: 14/02/2020

Accepted: 29/02/2020

Published: 03/03/2020

\begin{abstract}
Abstrak
Tujuan dari penelitian ini adalah untuk mengidentifikasi dan menyelidiki dan mendalami peluang dan hambatan mahasiswa doktoral dalam melakukan publikasi pada jurnal internasional bereputasi seperti Scopus dan Web of Science. Penelitian ini menggunakan metode kualitatif yaitu studi kasus eksploratif. Pengumpulan data primer menggunakan wawancara semi terstruktur dengan responden sebanyak 5 (lima) mahasiswa program doktoral di sebuah Universitas Swasta di Jakarta yang dipilih dan ditentukan dengan menggunakan metode purposive sampling. Hasil dari penelitian ini menunjukkan bahwa responden mahasiswa doktoral memiliki kesadaran dan minat yang positif untuk melakukan publikasi artikelnya di jurnal internasional bereputasi dengan beberapa tujuan utama, yakni: untuk memenuhi persyaratan kelulusan program doktoral, agar artikelnya disitasi penulis lainnya, untuk meningkatkan kompetensi, dan guna meningkatkan reputasi diri. Namun demikian, responden mahasiswa juga memiliki beberapa hambatan untuk melakukan publikasi pada jurnal internasioanl bereputasi seperti keterbatasan dana, keterbatasan waktu, kesulitan mencari referensi, waktu proses publikasi yang relative lama, keterbatasan kemampuan bahasa inggris, keterbatasan kemampuan penggunakan alat bantu software untuk pemeriksaan paper seperti similiarity test dan grammar test serta keterbatasan destinasi jurnal-jurnal internasional bereputasi yang akan menjadi tempat mempublikasikan artikelnya. Keterbatasan penelitian ini adalah jumlah sampel yang masih sedikit, yakni hanya lima orang dan subyek penelitian hanya pada mahasiswa program doktoral saja di universitas swasta di Jakarta dan belum tentu hasilnya sama jika penelitian dilakukan pada jenjang magister atau sarjana di universitas lain dan di tempat yang lain. Penelitian ini dapat menjadi referensi bagi penelitian sejenis selanjutnya di jenjang pendidikan yang berbeda, di universitas yang berbeda seperti di universitas negeri dan di tempat yang lain. Untuk penelitian selanjutnya dapat dikembangkan dengan metode kuantitatif dengan jumlah sampel yang lebih besar dan wilayah yang lebih luas misalnya lintas provinsi atau lintas negara.
\end{abstract}

Kata Kunci: Publikasi internasional, hambatan dan peluang, jurnal internasional bereputasi

\section{PENDAHULUAN}

Publikasi di jurnal internasional bereputasi seperti Scopus dan Web of Science merupakan alat untuk membangun reputasi individu mahasiswa. Dengan bantuan internet, artikel yang dimuat dapat dibaca dan disitasi setiap orang di dunia. Artikel yang disitasi berarti telah mengandung konten yang layak secara ilmiah 
(Agus Purwanto*, Rudy Pramono, Innocentius Bernarto, Masduki Asbari, Priyono Budi Santoso, Freddy Ong, Williana Kusumaningsih, Anggaripeni Mustikasiwi, Mirza Prameswari, Laksmi Mayesti Wijayanti, Choi Chi Hyun)

sebagai sumber kebenaran pengembangan keilmuan. Mahasiswa yang karya ilmiahnya banyak disitasi akan mendapatkan h-index dan impact factor yang tinggi sebagai bukti indikator pengakuan dunia akademik terhadap eksistensi dan kualitasnya. Kewajiban publikasi bagi mahasiswa tertuang dalam surat edaran menristekdikti nomor: B/323/B.B1/SE/2019 tentang publikasi ilmiah program sarjana, magister dan doktor. Di Antara isi edaran tersebut adalah bahwa program doktor menyusun disertasi dan makalah yang telah diterbitkan di jurnal internasional bereputasi dan lulusan program doktor terapan menyusun disertasi dan makalah yang telah diterbitkan di jurnal nasional terakreditasi minimal peringkat sinta 3 atau diterima di jurnal internasional atau karya yang dipresentasikan atau dipamerkan dalam forum internasional.

Melalui situs Scientific Journal Rankings (SJR) sampai dengan tahun tahun 2018, Indonesia berada pada peringkat 24 sedunia dengan jumlah publikasi 32.456, peringkat pertama adalah United States dengan jumlah publikasi 683.003, kedua China dengan jumlah publikasi 599.386 dan peringkat ketiga United Kingdom dengan junlah publikasi 211.710. Di level Asia, Indonesia berada pada peringkat 7 peringkat pertama yaitu China dengan 599.386 publikasi,peringkat kedua India dengan jumlah 171.356 publikasi dan peringkat ketiga Japan dengan 131.198 publikasi. Berdasarkan data dari Direktorat Jenderal Penguatan
Riset dan Pengembangan Kemristekdikti, jumlah publikasi ilmiah Indonesia terindeks Scopus per 6 April 2018 berhasil melampaui Singapura dan Thailand. Jumlah publikasi ilmiah internasional Indonesia sebanyak 5.125, sementara Singapura 4.948 dan Thailand sebanyak 3.741 dan Malaysia tetap unggul dengan 5.999. Peringkat publikasi ilmiah Indonesia terindeks Scopus akhirnya berhasil menyalip Malaysia dan menduduki posisi pertama di kawasan ASEAN. Dalam empat tahun belakangan ini, peningkatan jumlah publikasi ilmiah Indonesia mengalami kemajuan pesat, setelah melampaui Thailand di tahun 2017, Indonesia berhasil menggeser Singapura dan menduduki posisi kedua setelah Malaysia di tahun 2018. Terhitung per 9 September 2019, jumlah publikasi ilmiah Indonesia yang dihasilkan di 2018 dan sudah terbit di jurnal terindeks Scopus mencapai 34.007 publikasi. Angka ini untuk pertama kalinya menduduki posisi pertama di Asia Tenggara, diikuti oleh Malaysia sebanyak 33.286 publikasi. Jenis karya ilmiah sebagai syarat utama menduduki jenjang jabatan akademik tertentu dapat berbeda satu dengan yang lainnya. Jurnal internasional adalah jurnal yang memenuhi kriteria yaitu karya ilmiah yang diterbitkan ditulis dengan memenuhi kaidah ilmiah dan etika keilmuan, memiliki ISSN, ditulis dengan menggunakan bahasa resmi PBB (Inggris, Perancis, Arab, Rusia, dan Cina), memiliki terbitan versi online, dikelola secara profesional Editorial Board (Dewan Redaksi) adalah pakar di bidangnya dan biasanya berasal dari 
Jurnal Edumaspul, 4 (1), Year 2020 - 221

(Agus Purwanto*, Rudy Pramono, Innocentius Bernarto, Masduki Asbari, Priyono Budi Santoso, Freddy Ong, Williana Kusumaningsih, Anggaripeni Mustikasiwi, Mirza Prameswari, Laksmi Mayesti Wijayanti, Choi Chi Hyun)

\begin{tabular}{|c|c|c|c|c|}
\hline Initial & Jenis Kelamin & Usia & Status & Jurusan \\
\hline R1 & Perempuan & 32 & Single & S3 Manajemen \\
\hline R2 & Laki-Laki & 35 & Menikah & S3 Teknik \\
\hline R3 & Perempuan & 46 & Menikah & S3 MIPA \\
\hline R4 & Laki-Laki & 31 & Single & S3 Sastra \\
\hline R5 & Laki-laki & 38 & Menikah & S3 Hukum \\
\hline
\end{tabular}

berbagai negara. Artikel ilmiah yang diterbitkan dalam satu issue berasal dari penulis berbagai negara memuat karya ilmiah dari penulis yang berasal dari berbagai negara dalam setiap penerbitannya terindeks oleh database internasional bereputasi seperti Scopus dan Web of Science, Microsoft Academic Search dan atau laman sesuai dengan pertimbangan tim pakar Ditjen Dikti.

Beberapa mahasiswa pascasarjana terutama doktoral mengalami hambatan dalam publikasi jurnal international bereputasi yaitu kesibukan kerja, besarnya biaya yang tidak terjangkau, ketersediaan langganan jurnal dan online dan keterbatasan akses jurnal. Faktor penghambat produktivitas mahasiswa doktoral dalam publikasi karya ilmiah pada jurnal internasional terindeks bersumber dari faktor eksternal atau di luar diri mahasiswa yaitu kesibukan kerja, besarnya biaya, ketersediaan langganan jurnal cetak, ketersediaan langganan jurnal online, dan akses jurnal cetak. Banyak mahasiswa yang belum menerima ijazah karea belum melakukan publikasi di jurnal international bereputasi, bahkan ada beberapa perguruan tinggi yang menahan ratusan ijazah lulusan doktoral karena belum melakukan publikasi. Tujuan penelitian ini adalah untuk mengetahui faktor - faktor penghambat mahasiswa dalam melakukan publikasi international bereputasi dan peluang atau motivasi mahasiswa dalam melakukan publikasi international, subyek penelitian adalah mahasiswa doktoral di sebuah perguruan tinggi swasta di Jakarta.

\section{METODE PENELITIAN}

Penelitian menggunakan metode studi kasus eksplorasi dan pendekatan penelitiannya menggunakan metode kualitatif yaitu studi kasus eksploratif. Pengumpulan data primer menggunakan wawancara semi terstruktur dengan responden sebanyak 5 (lima) mahasiswa program doktoral di sebuah universitas swasta di Jakarta yang sudah dipilih dan ditentukan menggunakan metode purposive sampling. Untuk menjaga kerahasiaan, responden diberi inisial $\mathrm{R} 1, \mathrm{R} 2, \mathrm{R} 3, \mathrm{R} 4$ dan R5. Wawancara semi-terstruktur dilakukan melalui daftar pertanyaan yang disusun dan dikembangkan berdasarkan literatur terkait. Responden untuk penelitian ini adalah mahasiswa program doktoral di sebuah universitas swasta di Jakarta.

Tabel 1. Profil Responden

Responden sebanyak lima mahasiswa ditentukan dari jurusan yang berbeda. Metode pengumpulan data primer dengan wawancara semi-terstruktur. Sedangkan data sekunder dikumpulkan dari data yang dipublikasikan seperti artikel jurnal-jurnal dan buku. Penelitian ini terbatas pada ukuran sampel sebanyak lima responden mahasiswa program doktoral di sebuah universitas 
Jurnal Edumaspul, 4 (1), Year 2020 - 222

(Agus Purwanto*, Rudy Pramono, Innocentius Bernarto, Masduki Asbari, Priyono Budi Santoso, Freddy Ong, Williana Kusumaningsih, Anggaripeni Mustikasiwi, Mirza Prameswari, Laksmi Mayesti Wijayanti, Choi Chi Hyun)

swasta di Jakarta. Penelitian ini adalah studi kasus eksplorasi dan sampel dipilih menggunakan metode purposive sampling. Dalam penelitian kualitatif, teknik purposive sampling adalah metode yang digunakan untuk mencapai tujuan penelitian tertentu. Tidak ada batasan jumlah responden untuk membuat sampel purposive, asalkan informasi yang diinginkan dapat diperoleh dan dihasilkan (Bernard, 2002). Untuk melakukan penelitian studi kasus, Creswell (2013) memberikan pengamatan dan beberapa rekomendasi ukuran sampel, yang berkisar tidak lebih dari empat hingga lima kasus. Dalam studi kasus para responden diwawancarai hingga saturasi data tercapai dan tidak ada lagi informasi baru dapat diperoleh (Guest et al., 2006; Krysik \& Finn, 2010). Semua responden menyediakan lembar informasi sebelum wawancara. Untuk tempat wawancara dilakukan di lokasi yang nyaman bagi para responden. Semua wawancara, dengan izin dan persetujuan yang ditandatangani, direkam secara audio dan kemudian ditranskrip secara verbal.

Untuk mengetahui minat dan hambatan responden mahasiswa diberikan beberapa pertanyaan sebagai berikut:

1. Jelaskan motivasi anda untuk melakukan publikasi di jurnal internasional bereputasi ?

2. Jelaskan hambatan apa saja yang ada alami untuk melakukan publikasi di jurnal internasional bereputasi?

3. Apa manfaat yang ada rasakan jika artikel anda sudah dipublikasi di jurnal internasional bereputasi?

\section{HASIL DAN PEMBAHASAN}

Faktor - faktor penghambat mahasiswa dalam melakukan publikasi international bereputasi dan peluang atau motivasi mahasiswa dalam melakukan publikasi international akan dibahas pada bab ini dan sebagai subyek penelitian adalah mahasiswa doktoral di sebuah perguruan tinggi swasta di Jakarta.

\section{Peluang Publikasi pada Jurnal Internasional Bereputasi}

Seluruh responden memberikan pernyatan terkait peluang dna motivasi mereka untuk melakukan publikasi dan seluruh data pernyataanpernyataannya telah direduksi dan dikelompokkan pada tema yang sama atau mirip. Seluruh responden memberikan pernyatan terkait peluang dna motivasi mereka untuk melakukan publikasi dan seluruh data pernyataanpernyataannya telah direduksi dan dikelompokkan pada tema yang sama atau mirip. Reduksi data merupakan proses pemilihan, pemusatan perhatian pada penyederhanaan, pengabstrakan, transformasi data kasar yang muncul dari catatan-catatan lapangan" (Miles dan Huberman, 1992, hlm. 16). Sedangkan menurut Sugiyono (2007,) reduksi data adalah analisis data yang dilakukan dengan memilih hal-hal yang pokok, memfokuskan pada hal-hal yang penting, dan dicari tema serta polanya. Reduksi data berlangsung terusmenerus selama proyeksi penelitian berlangsung. Langkah-langkah yang dilakukan dalam reduksi data, di antaranya: menanjamkan analisis, menggolongkan atau mengkategorisasikan ke dalam tiap 
permasalahan melalui uraian singkat, mengarahkan, membuang yang tidak perlu, dan mengorganisasikan data, sehingga dapat ditarik kesimpulan dan diverifikasi. Data yang direduksi merupakan seluruh data mengenai permasalahan penelitian

\section{Pemenuhan Persyaratan Kelulusan}

Seluruh responden memberikan pernyataan terkait motivasinya membuat artikel untuk dipublikasikan di jurnal internasional bereputasi sebegai berikut:

"...saya mengirim publikasi agar bisa lulus karena sebagai salah satu syarat kelulusan doktoral.."(R1)

Pernyataan ini sama dengan pernyataan responden lainnya yaitu

"...saya akan publikasi artikel saya sebagai persyaratan kelulusan S3..."(R2)

"..agar bisa lulus tepat waktu makanya saya submit ke jurnal internasional bereputasi..."(R3)

" dengan adanya aturan baru setiap program S3 wajib publikasi makanya saya publish .."(R4)

Dan responden terakhir memberikan pernyataan yang sama.

"....saya submit paper ke jurnal internasional hanya karena pingin lulus. itu saja .."(R5)

Seluruh responden memberikan pernyataan bahwa mereka membuat artikel dan mengirimkan publikasi ke jurnal internasional bereputasi didorong oleh faktor pemenuhan persyaratan kelulusan, motivasinya agar bisa bisa lulus. Kewajiban publikasi bagi mahasiswa tertuang dalam surat edaran menristekdikti nomor:
B/323/B.B1/SE/2019 tentang publikasi ilmiah program sarjana, magister dan doktor yang isinya adalah program doktor menyusun disertasi dan makalah yang telah diterbitkan di jurnal internasional bereputasi dan lulusan program doktor terapan menyusun disertasid an makalah yang telah diterbitkan di jurnal nasional terakreditasi minimal peringkat sinta 3 atau diterima di jurnal internasional atau karya yang dipresentasikan atau dipamerkan dalam forum internasional

\section{Peningkatan Sitasi}

Beberapa responden juga memberikan pernyataan terkait motivasinya membuat artikel untuk dipublikasikan di jurnal internasional bereputasi sebagai berikut:

"...publikasi agar paper saya disitasi dan saya menjadi terkenal...."(R5)

Beberapa responden lain memberikan pernyataan yang hampir sama.

"...jika artikel saya disitasi maka impact factor artikel saya meningkat..."(R4)

"..jumlah sitasi membuat rangking saya di database jurnal bisa naik.."(R2)

Beberapa responden memberikan pernyataan bahwa mereka membuat artikel dan mengirimkan publikasi ke jurnal internasional bereputasi didorong oleh sebuah harapan artikelnya disitasi oleh penulis lain sehingga meningkatkan rangking dan impact factor di jurnal tersebut.

\section{Peningkatan Kompetensi}

Beberapa responden juga memberikan pernyataan terkait motivasinya membuat artikel untuk dipublikasikan di jurnal internasional bereputasi sebagai berikut: 
"...paper publish di jurnal bereputasi menunjukkan kompetensi saya...."(R3)

Beberapa responden lain memberikan pernyataan yang hampir sama.

"...artikel saya dimuat di jurnal bereputasi berati kemampuan saya bagus..."(R1)

Responden yang lain memberikan pernyataan yang mirip juga

"..kalau artikel publish berarti saya mampu membuat artikel setingkat nasional... "R4)

Beberapa responden memberikan pernyataan bahwa mereka artikel publikasi ke jurnal internasional bereputasi sebagai pembuktian kompetensi mereka dan menunjukkan bahwa mereka telah mampu untuk membuat artikel selevel internasional.

\section{Peningkatan Reputasi Diri}

Ada empat responden memberikan pernyataan terkait motivasinya membuat artikel untuk dipublikasikan di jurnal internasional bereputasi sebagai berikut:

"..artikel publish di jurnal bereputasi, saya bangga, reputasi saya naik..."(R2)

Beberapa responden lain memberikan pernyataan yang sama.

"...nama saya tertulis di jurnal international maka nama baik saya terangkat..."(R5)

Responden yang lain memberikan pernyataan yang sama

"..reputasi saya naik..makanya saya publish di jurnal yang berimpac factor tinggi “ R1)

"..saya bangga..punya ID jurnal..bisa naikin reputasi saya.."(R3)

Beberapa responden memberikan pernyataan bahwa mereka melakukan publikasi ke jurnal internasional bereputasi dengan harapan reputasi mereka bisa naik dan terciptanya nama baik.

\section{Hambatan Publikasi pada Jurnal Internasional Bereputasi}

Seluruh responden memberikan pernyatan terkait hambatan hambatan dan kendala mereka untuk melakukan publikasi dan seluruh data pernyataan-pernyataannya telah direduksi dan dikelompokkan pada tema yang sama atau mirip

\section{Keterbatasan Dana}

Seluruh responden memberikan pernyataan terkait hambatan dalam publikasikan di jurnal internasional bereputasi sebagai berikut:

"..biaya publikasi tidak terjangkau bagi saya...."(R1)

Beberapa responden lain memberikan pernyataan yang sama.

"...menurutku biayanya yang

Responden yang lain memberikan pernyataan yang hampir sama

"..biayanya terlalu mahal..walaupun ada yang gratis tapi sudah dan jarang " $\mathrm{R} 3$ ) "..kalau bisa fee nya yang murah dna jangan mahal...." (R4)

"..kayaknya hampir semuanya biayanya tinggi...." (R5)

Seluruh responden memberikan pernyataan bahwa hambatanhambatan mereka melakukan publikasi ke jurnal internasional bereputasi salah satunya adalah faktor biaya yang relative mahal. 
Keterbatasan Waktu

Seluruh responden

memberikan

pernyataan hambatannya dalam publikasikan di jurnal internasional bereputasi sebagai berikut:

"..saya kadang kesulitan membagi waktu untuk ngerjainnya...."(R1)

"...urusan kantor saya banyak, kadang belum sempat untuk membuat artikel..."(R2)

Responden yang lain memberikan pernyataan yang hampir sama

"..kadang saya nunggu waktu luang untuk membuat artikel..tetapi sudah juga kerjaan kantor banyak dan harus diselesaikan segera " $\mathrm{R} 3$ )

"..kadang saat di rumah mencoba mengerjakannya..tapi banyak juga urusan keluarga...." (R4)

"..karena waktu terbatas saya cicil tiap hari paling lama 1 jam untuk membuatnya......" (R5)

Seluruh responden memberikan pernyataan bahwa hambatanhambatan mereka melakukan publikasi ke jurnal internasional bereputasi salah satunya adalah faktor waktu untuk mengerjakan membuat artikel terbatas, karena banyak pekerjaan kantor dan keluarga.

\section{Kesulitan Mencari Referensi}

Beberapa responden memberikan pernyataan bahwa hambatannya dalam mempublikasikan papernya di jurnal internasional bereputasi sebagai berikut:

"..kadang saya kesulitan mencari referensi artikelnya...."(R3)

"...saya mencari referensi di internet, kadang berbayar dna tertutup..."(R1)

Responden yang lain memberikan pernyataan yang $\mathrm{h}$ sama "..untuk referensi yang berkualitas yang mendukung artikel saya susah mencarinya, kebanyakan berbayar " R5)

Sebagian responden memberikan pernyataan bahwa hambatanhambatan mereka melakukan publikasi ke jurnal internasional bereputasi salah satunya adalah kesulitan mendapatkan referensireferensi artikel, karena kebanyakan adalah tertutup dan berbayar.

\section{Proses Publikasi Relatif Lama}

Seluruh responden memberikan pernyataan hambatannya dalam publikasikan di jurnal internasional bereputasi sebagai berikut:

"..saya sering submit paper, waktunya lama 12 bulan...."(R3)

"...prosesnya lama..4 sampai 9 bulan..."(R2)

Responden yang lain memberikan pernyataan yang sama

"..lama saya menunggu..hampir 10 bulan baru publish "(R5)

Seluruh responden memberikan pernyataan bahwa hambatanhambatan mereka melakukan publikasi ke jurnal internasional bereputasi salah satunya adalah waktu publikasi yang relatif lama.

\section{Keterbatasan Kemampuan Bahasa Asing}

Sebagian responden memberikan pernyataan hambatannya dalam publikasikan di jurnal internasional bereputasi sebagai berikut:

"..saya pernah ditolak..grammarnya kurang bagus katanya...."(R4) 
"...pernah ada kome rebiewer..bahasa inggrisnya susah dipahami..."(R3)

Responden yang lain memberikan pernyataan yang hampir sama

"..saya pakai jasa penterjemah, karena kemampuan saya bahasa asing kurang “(R1)

Ada tiga responden memberikan pernyataan bahwa hambatanhambatan mereka melakukan publikasi ke jurnal internasional bereputasi karena keterbatasan penguasaan bahasa asing dan kualitas tata bahasa baku. Very (2018) menjelaskan bahwa kekurangan sebuah tulisan terdapat pada aspek kebahasaan. Kebahasaan juga menjadi hambatan mahasiswa untuk melakukan penelitian. Bahasa Inggris dijadikan sebagai bahasa kedua baik dalam proses kegiatan formal maupun nonformal. Penggunaan bahasa asing sebagai alat komunikasi lisan sering dijumpai dalam komunikasi sehari-hari. $\mathrm{Hal}$ ini diketahui dikarenakan kurangnya praktik memakai bahasa asing bisa menjadi salah satu faktor kesulitan dalam menguasai bahasa asing

\section{Keterbatasan Kemampuan Penggunakan Alat Bantu Software}

Sebagian responden memberikan pernyataan hambatannya dalam publikasikan di jurnal internasional bereputasi sebagai berikut:

"..paper saya sering ditolak. similiaritynya $40 \%$, saya tidak punya dan tidak bisa pakai tool plagiasi checker nya...."(R4) "...grammar saya jelek katanya, saya disuruh pakai grammarly..."(R1)

"..saya dikomentari reviewer suruh pakai program mendeley..padahal; saya kagak tahu pakainya " (R5)

Ada tiga responden memberikan pernyataan bahwa hambatanhambatan mereka melakukan publikasi ke jurnal internasional bereputasi karena keterbatasan penguasaan penggunaaan software atau program untuk pengecekan kualitas artikel seperti similiarti, grammar dna daftar pustaka.

\section{Keterbatasan Informasi Jurnal Internasional Bereputasi}

Sebagian responden memberikan pernyataan hambatannya dalam publikasikan di jurnal internasional bereputasi sebagai berikut:

"..saya pernah ditolak, karena tidak sesuai gaya selingkungnya, scopenya..saya kesulitan mencari jurnal yang sesuai scope artikel saya...."(R3)

"...saya kadang kesulitan mencari jurnal yang sesuai dengan tema artikel saya..."(R2)

"..kadang saya suruh mencarikan teman jurnal yg cocok dengan paper saya, karena saya tidka tahu dimana mencarinya "(R4)

Ada tiga responden memberikan pernyataan bahwa hambatanhambatan mereka melakukan publikasi ke jurnal internasional bereputasi karena keterbatasan informasi dan kesulitan mendapatkan jurnal yang sesuai dengan lingkup artikelnya. (Very, 2018). Produktivitas penelitian di Indonesia cenderung 
tertinggal karena aktivitas pengajaran di universitas lebih ditekankan pada proses pembelajaran daripada penelitian. Hambatan lain yang muncul dalam bentuk keterbatasan fasilitas, contohnya kasus yang sering terjadi ialah banyak nya perpustakaan yang tidak dilengkapi dengan database jurnal yang up to date, belum terotomatisasinya laboratorium dan juga peralatan yang memadai, serta kurangnya pendanaan dan juga reward yang sepadan guna melakukan penelitian. (Very, 2018)

\section{KESIMPULAN}

Faktor-faktor peluang atau motivasi dalam melakukan publikasi international bereputasi

pada mahasiswa doktoral di sebuah perguruan tinggi swasta di Jakarta dapat disimpulkan sebagai berikut: sebagai pemenuhan persyaratan kelulusan, untuk meningkatkan sitasi artikelnya, sebagai pembuktian kompetensi mereka dan menunjukkan bahwa mereka telah mampu untuk membuat artikel selevel internasional, melakukan publikasi ke jurnal internasional bereputasi dengan harapan reputasi mereka bisa naik dan terciptanya nama baik. Sedangkan factor-faktor yang menjadi hambatan mereka melakukan publikasi ke jurnal internasional bereputasi adalah sebagai berikut: faktor biaya yang relatif mahal, faktor waktu untuk mengerjakan membuat artikel terbatas karena banyak pekerjaan kantor dan keluarga, kesulitan mendapatkan referensi-referensi artikel karena kebanyakan adalah tertutup dan berbayar, proses waktu publikasi yang relatif lama, keterbatasan penguasaan penggunaaan software atau program untuk pengecekan kualitas artikel seperti similiarti, grammar dan daftar pustaka, dan keterbatasan informasi serta kesulitan mendapatkan destinasi jurnal yang sesuai dengan lingkup artikelnya.

Keterbatasan penelitian ini adalah jumlah sampel yang sedikit hanya 5 orang dan subyek penelitian hanya pada mahasiswa program doktoral saja di universitas swasta di Jakarta dan belum tentu hasilnya sama jika penelitian dilakukan pada jenjang magister atau sarjana di universitas lain dan di tempat yang lain. Penelitian ini dapat menjadi referensi bagi penelitian selanjutnya di jenjang pendidikan yang berbeda, di universitas yang berbeda seperti di universitas negeri dan di tempat yang lain. Untuk penelitian selanjutnya dapat dikembangkan dengan metode kuantitatif dengan jumlah sampel yang lebih besar dan wilayah yang lebih luas misalnya lintas provinsi atau lintas negara.

\section{Daftar Pustaka}

[1] Bernard, H.R. (2002), Research Methods in Anthropology: Qualitative and Quantitative Methods, 3rd ed., Altamira Press, Walnut Creek, CA.

[2] Creswell, J.W. (2007), Qualitative Inquiry and Research Design. Choosing among Five Approaches, Sage Publications, Los Angeles.

[3] Creswell, J.W. (2009), Research Design: Qualitative, Quantitative, and Mixed Methods Approaches, 3rd ed., SAGE Publications, Incorporated, Los Angeles.

[4] Creswell, J.W. (2013), Qualitative Inquiry and Research Design: Choosing among Five Approaches, 3rd ed., Sage, Thousand Oaks, CA.

[5] Guest, G., Bunce, A. and Johnson, L. (2006), "How many interviews are enough? An experiment with 
Jurnal Edumaspul, 4 (1), Year 2020 - 228

(Agus Purwanto*, Rudy Pramono, Innocentius Bernarto, Masduki Asbari, Priyono Budi Santoso, Freddy Ong, Williana

Kusumaningsih, Anggaripeni Mustikasiwi, Mirza Prameswari, Laksmi Mayesti Wijayanti, Choi Chi Hyun)

data saturation and variability", Field Methods, Vol. 18 No. 1, pp. 59-82.

[6] Krysik, J.L. and Finn, J. (2010), Research for Effective Social Work Practice, 2nd ed., Routledge, New York, NY.

[7] Miles, B. M., \& Huberman, M. (1992). Analisis Data Kualitatif Buku Sumber tentang Metodemetode Baru. Jakarta: UIP.

[8] Sugiyono (2007). Metode Penelitian Pendidikan Pendekatan Kuantitatif, Kualitatif, dan R\&D. Bandung: Alfabeta.

[9] Journals Rangking All Region . https://www.scimagojr.com/journalr ank.php?type $=\mathrm{j}$

[10] Journals Rangking Asiatic Reghion . (2020). Scimago. Diambil https://www.scimagojr.com/journalr ank.php?type $=$ i\&country=Asiatic $\%$ 20Region.

[11] Very Julianto.(2018).Faktor-Faktor Penghambat Meningkatnya Kemampuan Publikasi di Program Studi Psikologi UIN Sunan Kalijaga Yogyakarta, Jurnal Psikologi Integratif Prodi Psikologi UIN Sunan Kalijaga, 6(2),131-140 (2020). Scimago. Diambil dari 